\title{
An Indian Scenario: Emerging Advances in Nanotechnology as Drug Delivery System in Rheumatoid Arthritis
}

\author{
U.B. Wahul ${ }^{1}$, L.H Kamble ${ }^{2 *}$, A.S. Kadam ${ }^{2}$ \\ ${ }^{1 *}$ School of life Sciences, Swami Ramanand Teerth Marathwada University, Nanded, India \\ ${ }^{2}$ School of life Sciences, Swami Ramanand Teerth Marathwada University, Nanded, India \\ ${ }^{3}$ Dept. of Botany, DSM Arts, Commerce, Science College, Jintur, Parbhani, India \\ "Corresponding Author: lhkamble@gmail.com, Tel.: +91(90110)(10314)
}

Available online at: www.isroset.org

Received 17/Jan/2018, Revised 30/Jan/2018, Accepted 22/Feb/2018, Online 28/Feb/2018

\begin{abstract}
There are several significant assays including bioavailability, Toxicity, high clearance, and further current therapies require higher and frequent dosing to gain desired therapeutic effects for Rheumatoid arthritis (RA). Nanoparticles have been widely investigated for rheumatoid arthritis (RA). Though, higher doses of Nanocarriers also increase the incidence of dreadful adverse effects. Wherever, nanocarrier properties are most populated by the use of different approaches like targeting ligands, to change the physicochemical properties including higher encapsulation, better penetrating ability in cells etc. The main advantage of the nanocarrier that they provide longer circulation which enhances drug localization at the inflamed site and selective targeting to enhance the therapeutic index of anti-arthritic drugs. However, the optimal properties of nanocarrier also depend on the route of administration and size of particles, thus larger size show more retention upon local injection and smaller sized ones are more optimal for passive targeting. The present article discusses the emergence of nano-carriers for antirheumatic drugs, which delivers drug molecule to the inflamed site by topical, intra-articular (i.a) and intra-venous (i.v) administration to take advantage of therapeutic efficacy by passive and active drug delivery. Advancements have been made extensively but still better investigations are needed to achieve the risk-benefit ratio for the development of safe, stable and effective targeting nanocarriers for the e treatment of rheumatoid arthritis (RA).
\end{abstract}

Keywords-Rheumatoid Arthritis, Topical delivery, Transferosomes, Nanomedicine, Liposomes, Nanocarrier etc.

\section{INTRODUCTION}

Arthritis is a golden crown term for joint autoimmune disorders that involves the inflammation of one or more joints or the musculoskeletal system. Arthritis and joint diseases have been plaguing mankind since ancient times. In around $1500 \mathrm{BC}$ the Ebers Papyrus described a condition that is similar to RA. There is also evidence of RA in the Egyptian mummies as found in several studies [1].

In the Indian literature, charak samhita (written in around 300-200 BC) also described a condition that describes pain, joint swelling and loss of joint mobility and function. Hippocrates described arthritis in general in 400 BC Galen between 129 and $216 \mathrm{AD}$ introduced the term rheumatisms. Paracelsus (1493-1511) suggested that, could not be passed urine got stored and collected in the body especially in the joints and this caused arthritis. Ayurveda in ancient Indian medicine also considered arthritis as one of the Vata [1].

With the increase in the ageing population, the number of people with arthritis is also growing; hence the current trends suggest that arthritis affects the $1 \%$ of people i.e. over 180 million (2005) people in India. This study shows the higher prevalence of arthritis than many well known diseases such as diabetes, AIDS and cancer. The current trend suggests the percentage of these disorders would be $10 \%$ in India by 2020 , in comparison with other countries (Table - 1).

Table - 1 Research Review Present the No. of patient affected in the major country of world [2].

\begin{tabular}{|c|c|c|}
\hline $\begin{array}{l}\text { Country } \\
\text { Name }\end{array}$ & Year & $\begin{array}{c}\text { No. of patient of } \\
\text { Rheumatoid Arthritis } \\
\text { (Total Population) }\end{array}$ \\
\hline India & 2005 & 1 million \\
\hline Australia & $\begin{array}{c}\text { 2017/2050 } \\
\text { (http://arthritisau } \\
\text { stralia.com.au) }\end{array}$ & 3.85 Milion/7 Million \\
\hline America & $1995 / 2020$ & 40 Million/59.4 Million \\
\hline Japan & 2009 & $7,60,000$ \\
\hline
\end{tabular}

Worldwide statistics (http://who.int/) shows that the RA leads to a major health burden in globally. Globally 291 condition of studied, RA was ranked as the $42^{\text {nd }}$ highest contributor to global disability, just below malaria and just above iodine deficiency [3]. 
The limited study population carried out in India shown in (Table-2).

Table - 2: Literature survey held in different region of India [4].

\begin{tabular}{|c|c|c|c|}
\hline $\begin{array}{c}\text { Author(s) and title of } \\
\text { publication }\end{array}$ & $\begin{array}{l}\text { Time } \\
\text { period }\end{array}$ & $\begin{array}{l}\text { Geographic } \\
\text { coverage }\end{array}$ & $\begin{array}{c}\text { Patient } \\
\text { Popula } \\
\text { tion } \\
\text { size }\end{array}$ \\
\hline $\begin{array}{l}\text { Chopra A, Raghunath } \\
\mathrm{D} \text {, Singh A et al. The } \\
\text { pattern of rheumatoid } \\
\text { arthritis in the Indian } \\
\text { population: } \\
\text { prospective study. }\end{array}$ & $\begin{array}{l}1981- \\
1987\end{array}$ & $\begin{array}{c}\text { Pune } \\
\text { Maharashtra }\end{array}$ & 110 \\
\hline $\begin{array}{l}\text { Bhatt AD, Sane SP, } \\
\text { Vaidya AB et al. } \\
\text { Patterns of rheumatic } \\
\text { diseases } \\
\text { antirheumatic and } \\
\text { usage in } 11931 \text { Indian } \\
\text { patients. }\end{array}$ & 1993 & Nationwide & 11931 \\
\hline $\begin{array}{l}\text { Malaviya, AN, Kapoor, } \\
\text { SK, Singh, RR et al. } \\
\text { Prevalence } \\
\text { rheumatoid arthritis in } \\
\text { the adult Indian } \\
\text { population. }\end{array}$ & 1993 & $\begin{array}{l}\text { Five villages } \\
\text { of } \\
\text { Ballabhgarh } \\
\text { township, } \\
\text { Haryana }\end{array}$ & 39826 \\
\hline $\begin{array}{lr}\text { Kar N. A short } \\
\text { communication } & \text { on } \\
\text { occurrence } & \text { of } \\
\text { rheumatic diseases } \\
\text { attending hospital. }\end{array}$ & 1994 & West Bengal & 4800 \\
\hline $\begin{array}{l}\text { Agrawal S, Aggarwal } \\
\text { A, Dabadghao S et al. } \\
\text { Compound } \\
\text { heterozygosity of } \\
\text { HLA-DR4 and DR1 } \\
\text { antigens in Asian } \\
\text { Indians increases the } \\
\text { risk of extra-articular } \\
\text { features in rheumatoid } \\
\text { arthritis. }\end{array}$ & 1995 & $\begin{array}{l}\text { Uttar } \\
\text { Pradesh }\end{array}$ & 74 \\
\hline $\begin{array}{l}\text { Chopra A, Patil J, } \\
\text { Billempelly } \mathrm{V} \text { et al. } \\
\text { Prevalence } \\
\text { rheumatic diseases in a } \\
\text { rural population in } \\
\text { western India: a WHO- } \\
\text { ILAR COPCORD } \\
\text { Study. }\end{array}$ & 2001 & $\begin{array}{l}\text { Bhigwan, } \\
\text { Pune } \\
\text { Maharashtra }\end{array}$ & 5998 \\
\hline $\begin{array}{l}\text { Mahajan A, Jasrotia } \\
\text { DS, Manhas AS et al. } \\
\text { Prevalence of major }\end{array}$ & 2003 & $\begin{array}{c}\text { Jammu } \\
\text { (Jammu and }\end{array}$ & 1014 \\
\hline
\end{tabular}

\begin{tabular}{|c|c|c|c|}
\hline $\begin{array}{l}\text { rheumatic disorders in } \\
\text { Jammu. }\end{array}$ & & Kashmir) & \\
\hline $\begin{array}{l}\text { Wakhlu A, Gupta D, } \\
\text { Aggarwal A et al. Low } \\
\text { levels of anti-histone } \\
\text { antibodies in north } \\
\text { Indian children with } \\
\text { juvenile rheumatoid } \\
\text { arthritis. }\end{array}$ & 2003 & $\begin{array}{l}\text { Lucknow } \\
\text { (Uttar } \\
\text { Pradesh) }\end{array}$ & 148 \\
\hline $\begin{array}{l}\text { Wakhlu A, Krisnani N, } \\
\text { Hissaria P et al. } \\
\text { Prevalence } \\
\text { secondary amyloidosis } \\
\text { in Asian North Indian } \\
\text { patients } \\
\text { rheumatoid arthritis. }\end{array}$ & 2003 & $\begin{array}{l}\text { Lucknow } \\
\text { (Uttar } \\
\text { Pradesh) }\end{array}$ & 113 \\
\hline $\begin{array}{l}\text { Aggarwal A, Agarwal } \\
\text { V, Danda D et al. } \\
\text { Outcome in juvenile } \\
\text { rheumatoid arthritis in } \\
\text { India. }\end{array}$ & 2004 & $\begin{array}{l}\text { Lucknow } \\
\text { (Uttar } \\
\text { Pradesh) }\end{array}$ & 214 \\
\hline
\end{tabular}

\section{RELATED WORK}

\section{Molecular targets and therapies available for arthritis:}

The treatment of arthritis includes the use of immunosuppressive drugs which might have the several side effects. The role of immunosuppressive drugs is to inhibit the functions of blocking the signal through heterodimeric receptors.

In these cases of autoimmune disorder the mechanism of Anti-arthritis drug carried out by the inhibiting function of JAK signalling through JAK1 and JAK3 heterodimeric receptor of JAK. By blocking of these receptors (JAK1 and JAK3) leads to the blocking of several cytokines such as interleukins (ILs) 2,4,7,9 and 21 which contribute in modulating immune response.

As discussed earlier the immunosuppressive drugs involve serious side effects like bronchitis, liver abscess, tuberculous pleural effusion [5] etc.

\section{Literature Experimentation for OA:}

In the year 2014 , over 20 research publications have reported the development of various nanocarrier (NC) systems for delivery of synthetic or natural anti-inflammatory compounds for regenerative medicine drug delivery model. Most of these NPs were biodegradable including chitosan (CS)-coated calcium phosphate encapsulating iron saturated bovine lactoferrin for delivery of bovine lactoferine in invitro inflammatory disease model of mice [6]. 
Oral administration of these NCs in mice was found to be non-toxic and induced disease reversal by reducing inflammation and significantly inhibiting the expression of catabolic genes, IL-1 $\beta$, nitric oxide, c-Jun N-terminal kinase, and MAPK. The calcium phosphate encapsulating iron saturated bovine lactoferrin NCs showed the ability to completely dissolve the calcium pyrophosphate crystals in mice inflammatory site indicating their therapeutic ability to be used as a treatment for chronic inflammatory diseases such as OA [7].

\section{METHOdology}

\section{Mechanism of action in JAK Pathways:}

In these cases of mechanism of regulation, JAK-STAT pathways play an important role;

\section{In the absence of inhibitor:}

The Janus kinase consist of 3 protein kinases i.e. JAK1, JAK2, JAK3 and 1 TYK2 kinase interact with intracellular portion of cytokine receptor and play important role in signal transduction pathways for many pro inflammatory cytokine such as IL 2, 4, 7, 9, 13, 15, 17, 21, 23. Which are involved in pathogenesis of IBD (Inflammatory Bowel DiseaseInflammatory condition of colon or small intestine).

In this pathway of JAK1 and JAK3 modulate the immunoresponse with the help of IL 2, 4, 7, 9, 15, 21 signalling. JAK1 and JAK3 modulate the response with other cytokine receptor also but it transcript with common modulating pathway called STAT (Signal transducer and activator of transcription).

In this regards with $\mathrm{R}$. arthritis the mechanism of action starts with the binding of cytokine to the intracellular cytokine receptor, as the cytokine binds to the receptor it makes certain conformational changes where the JAK 1 and 3 gets activated and goes in the association with phosphorylation. After activation of JAK 1 and 3, activated JAK then phosphorylates specific residue on receptor domain, which serve as docking site for the STAT. After docking the STAT proteins get phosporylated, and dissociated from receptor chain and form dimmers. This dimmer gets translocated to the nucleus for further activation of gene transcription which resulted into the Proinflammatory gene transcription and expression (Shown in Figure - 1).

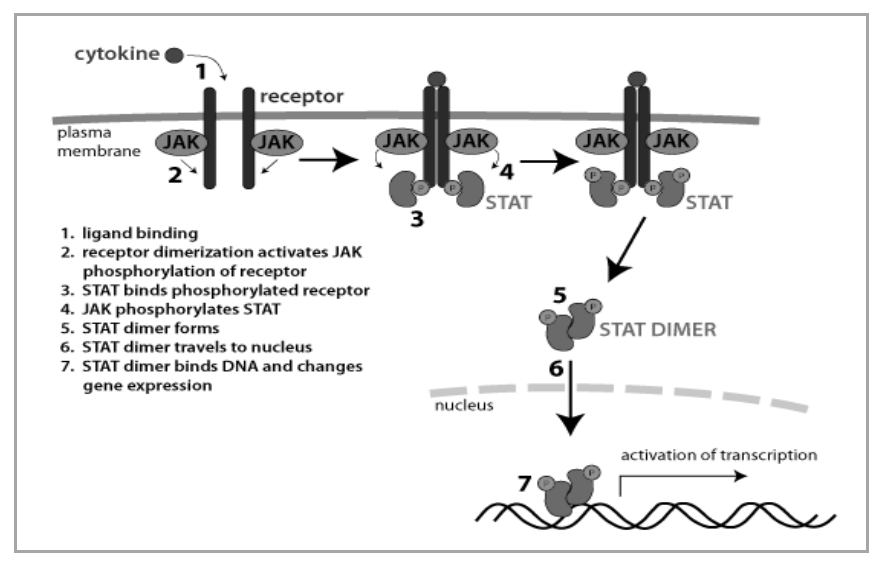

Figure 1 -Mechanism of regulation of JAK Protein Molecule.

\section{In the presence of Inhibitor:}

In the presence of inhibitor, it gets bind to the JAK protein, and inhibits the whole cycle to be takes place such as; a) JAK activation prevented, b) No phosphorylation of receptor subunits, c) No docking site for STAT phosphrylation, d) hence no translocation of STAT dimmer complex to the nucleus, e) and hence no transcription of pro inflammatory genes. The presence of inhibitor can also leads to the prevention of IL17 cytokine from TH Cells.

It makes full understanding that, the presence of inhibitor not only inhibits the action of single cytokine but also involves in the inhibition of multiple cytokine production, hence affect the other pathway also (Figure -2).

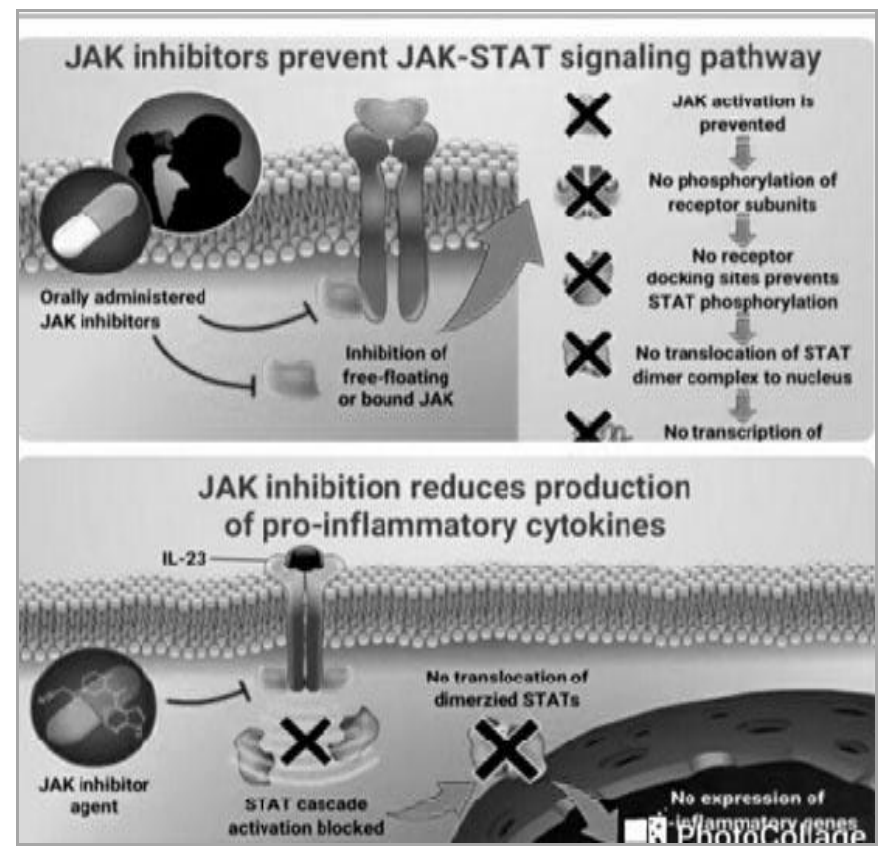

Figure 2- Inhibition of JAK Receptors by Immunosuppressive Drug and hence the JAK cycle 


\section{RESULTS AND DISCUSSION}

\section{Action of NC's at arthritic inflammatory site:}

In this instance of action of NC's therapy, for e.g. in at knee joint, Nanoparticle injected into the inflammatory site of synovial joint, where the nanoparticles bound to the cartilage component and released the drug within the cartilage matrix and follows the JAK - STAT Pathway to inhibit the expression of specified cytokine for it is made up of i.e. Inflammatory IL cytokines. (Table -3).

Table - 3: Nanocarrier or Nanoparticle (NP) used for the drug delivery in rheumatoid arthritis

\begin{tabular}{|c|c|c|}
\hline Sr. No & Nanoparticle System & $\begin{array}{c}\text { Immunosuppressive } \\
\text { Receptor/Drug }\end{array}$ \\
\hline 1 & Non-anticoagulant heparin & $\begin{array}{l}\text { Inhibitor of the TLR induced } \\
\text { inflammation }\end{array}$ \\
\hline 2 & Chitosan's NP's & Anti TNF- $\alpha$ siRNA \\
\hline 3 & Thiolated glycol chitosan & Polymerized siRNA \\
\hline 4 & $\begin{array}{l}\text { Chitosan (CS) or calcium } \\
\text { phosphate encapsulating iron } \\
\text { saturated bovine lactoferrin } \\
\text { NP's }\end{array}$ & Plasmid DNA \\
\hline 5 & $\begin{array}{l}\text { Polysialic Acid-Trimethyl } \\
\text { chitosan (NP's) }\end{array}$ & $\begin{array}{l}\text { Dexamethasone and } \\
\text { methotrexate }\end{array}$ \\
\hline 6 & Solid-Lipid Nanoparticles & Curcumin \\
\hline 7 & Perflurocarbon NP's & Lipase labile fumagillin \\
\hline 8 & $\begin{array}{l}\text { Poly (Lactic-co-glycolic acid) } \\
\text { (PLGA) NP's }\end{array}$ & Methotrexate \\
\hline 9 & Hyaluronate-gold-nanoparticle & Tocilizumab \\
\hline 10 & $\begin{array}{l}\text { Therapeutic gold }(\mathrm{Au}) \text { half } \\
\text { shell NP's }\end{array}$ & Methotrexate \\
\hline
\end{tabular}

The mechanism of action of Nano-particle at knee joint shown in Figure 3.

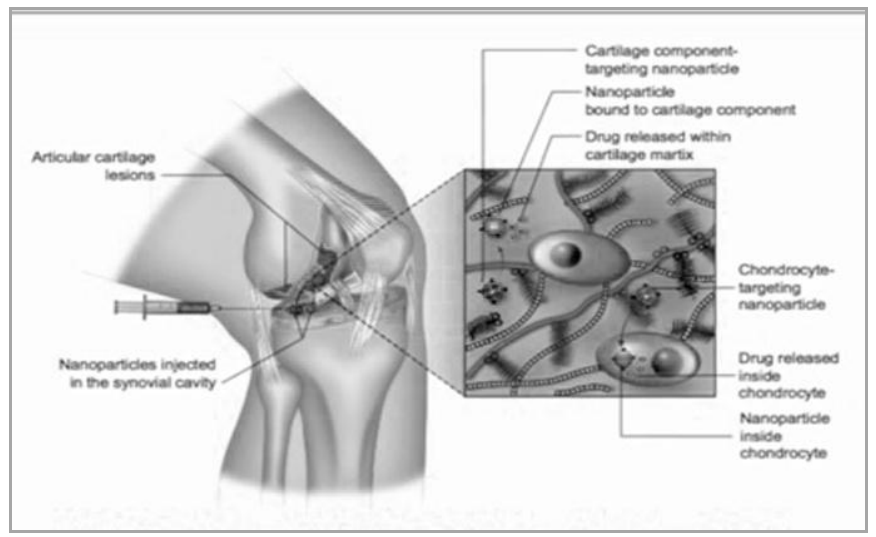

Figure 3 -Mechanistic approach of Nanocarriers with immunosuppressant drug.

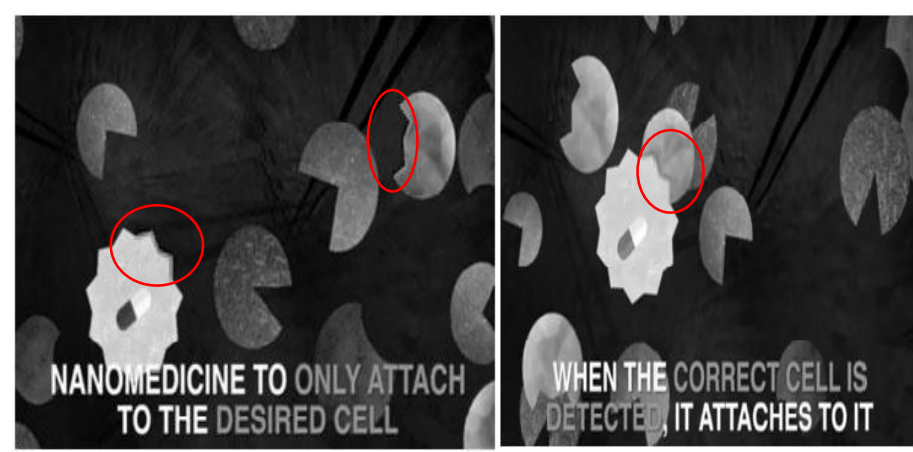

Figure 4-Binding of Nanocarrier with drug, to affect cell and gives the immunoresponse.

\section{CONClusion AND Future SCOPE}

As rheumatoid arthritis is known to be the autoimmune disorder and common inflammatory disease characterized by the inflammation in joints. As well as the bones, cartilages destruction this results in to the unbalanced functioning of cell protein and their receptor.

So we can predict the ray of hope here in these article, as investigated in the research; nanoparticles as used in the other processes of medicine like in regenerative medicines including; skin regeneration, nerve regeneration, dental regeneration, ocular regeneration etc [8]. It could be used in to the treatment of R. Arthritis.

Use of nanoparticles such as chitosan, non anticoagulant heparin, thiolated glycol chitosan, Bovine lactoferin and variety of other nanocarrier have ability to suppress the activity of inflammatory gene expression this results into the prevention of pain in joints, bone, cartilage destruction etc. While having anti-inflammatory effect it doesn't show the effect of toxicity.

Targeted drug delivery, via nanocarrier has achieved a bit of success, still not many biodegradable and non toxic nanoparticles have been explored to treat such known kind of autoimmune diseases.

\section{ACKNOWLEDGMENT}

I would like to thanks to Dept. of Pharmacy, SRTM University campus, Nanded for support me in an opportunity to review the reference study. Also "thanks to the guide L. Kamble" for endeavouring me time to time support.

\section{REFERENCES}

[1] D.Reddy, L.W.Trost, T.Lee, A.Baluch, A.D Kay; Rheumatoid Arthritis: Current Pharmacologic Treatment and Anasthteic onsiderations, M.E.J. ANESTH Vol.19, Issue (2), 2007. 
[2] Kislay Roy, Rupinder Kaur Kumar, Jagat Rakesh Kumar; Molecular targets in arthritis and recent trends in nano therapy; International journal of Medicine; Vol.10, Issue 1, pp.5407-5420, 2015.

[3] Cross M, Smith E, Hoy D, et al, The global burden of rheumatoid arthritis: estimates from the Global Burden of Disease 2010 study; Annals of the Rheumatic Diseases;Vol.73; pp.1316-1322, 2014.

[4] R.Handa, U.R.K. Rao, Juliana F.M Lewis, Gautam Rambhad, Susan Shiff, Canna J.Ghia; Literature review of rheumatoid arthritis in India; International journal of Rheumatic Diseases; Vol.19, Issue 5, pp.440-451. 2016.

[5] van der Heijde D, Tanaka Y, Fleischmann R, et al. Tofacitinib (CP-690,550) in patients with rheumatoid arthritis receiving methotrexate: twelve-month data from a twenty-four-month phase III randomized radiographic study. Arthritis Rheum.; Vol. 65, Issue.(3), pp. 559-570, 2013.

[6] Wiesenthal A, Hunter L, Wang S, Wickliffe J, Wilkerson M. Nanoparticles: small and mighty. Int J Dermatol.;Vol. 50 Issue: (3), pp. 247-254, 2011.

[7] Zolnik BS, Gonzalez-Fernandez A, Sadrieh N, Dobrovolskaia MA. Minireview: nanoparticles and the immune system. Endocrinology.; Vol. 151, Issue. (2):pp. 458-465, 2010.

[8] Koel Chaudhury, Vishu Kumar, Jayaprakash Kandasamy, Sourav Roy Choudhury; "Regenerative nanomedicine: current perspectives and future directions". International Journal of Nanomedicine: Vol. 9 pp. 4153-4167, 2014.

\section{AUTHORS PROFILE}

Umesh B. Wahul pursed M.Sc. Biotech and currently pursuing Ph.D. in life sciences from SRTMU, Nanded, India in 2012, 2019 respectively. He is a member of ISCA, India since 2014; He has published $3+$ research papers in reputed international journals including His main research work focuses on Antidiabetic Drug Characterization and Discovery. He has 2 years of teaching experience and $3+$ years of research experience. 